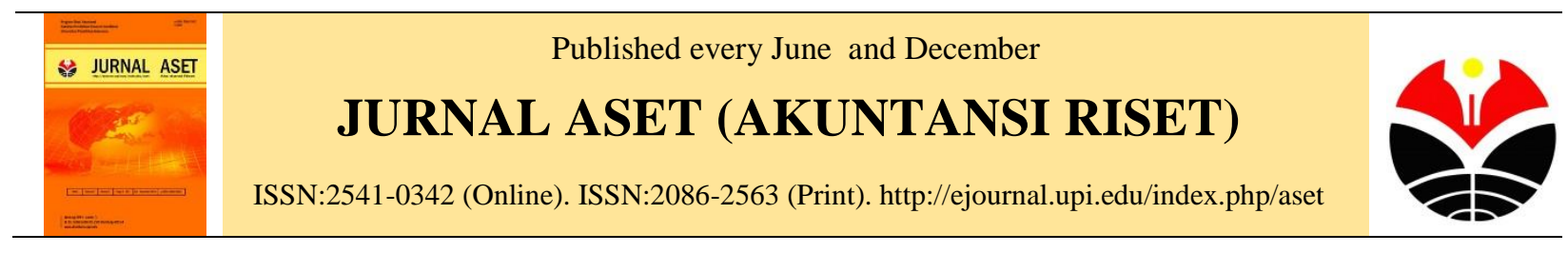

\title{
Analisis Faktor-Faktor Yang Mempengaruhi Penerapan Whistleblowing System Di Indonesia
}

\author{
Cyntia Ayu Wardani ${ }^{1}$, Sulhani $^{2}$ \\ Sekolah Tinggi Ekonomi Islam Tazkia \\ cyntiawww@gmail.com¹, sulhani@tazkia.ac.id ${ }^{2}$
}

\begin{abstract}
Whistleblowing system is part of the internal control that has not been widely discussed in accounting research in Indonesia. This study aims to provide empirical evidence about the factors that effect the effective application of the whistleblwoing system in Indonesia. samples of this research are listed companises in Indonesian Stock Exchange in 2013. The analysis method used in this research is data multiple regression. The result of this study indicate that anonymous reporting has a significant influence on the application of the whistleblowing system. This is in line with Lee and Fergher (2012) which states that companies that allow anonymous reporting tends to support the application of the whistleblowing system. While other factors such as total assets, inventory and external directors on the audit committee did not significantly affect the application of whistleblowing system. The implication of this research is company must have a whistleblower protection policy for efective whistleblowing system application.
\end{abstract}

Keywords: Whistleblwoing System, Anonymous Reporting

Abstrak. Whistleblowing system merupakan bagian dari pengendalian internal yang belum banyak dibahas dalam penelitian akuntansi di Indonesia. Penelitian ini bertujuan untuk memberikan bukti empiris mengenai faktor-faktor yang mempengaruhi efektifitas penerapan whistleblowing system di Indonesia pada perusahaan yang terdaftar di Bursa Efek Indonesia tahun 2013. Metode analisis yang digunakan dalam penelitian ini adalah regresi data berganda.Hasil penelitian ini menunjukkan bahwa anonymous reporting memiliki pengaruh signifikan terhadap penerapan whistleblowing system. Hal ini sejalan dengan Lee dan Fergher (2012) yang menyatakan bahwa perusahaan yang mengizinkan pelaporan secara anonim cenderung mendukung penerapan whistleblowing system. Sedangkan faktor lainnya seperti total assets, inventory dan external director dalam komite audit tidak berpengaruh signifikan terhadap penerapan whistleblwoing system. Implikasi dari penelitian ini adalah perusahaan perlu menjamin keamanan para pelpaor dalam whistleblowing system.

Kata Kunci: Whsitleblowing system,Anonymous Reporting

Corresponding Author. cyntiawww@gmail.com, sulhani@ tazkia.ac.id

How to Cite This Article. Wardani, Sulhani. Analisis Faktor-Faktor Yang Mempengaruhi Penerapan

Whistleblowing System Di Indonesia. Jurnal Akuntansi Riset. Program Studi Akuntansi. Fakultas Pendidikan Ekonomi dan Bisnis Universitas Pendidikan Indonesia, 9(1), 29-44

History of Article. Received : 17-11-2016, Revision: 08-12-2016, Published: 14-02-2017

PENDAHULUAN 
Berdasarkan hasil "13Th Global Fraud Survey" yang dilakukan oleh Ernst \& Young pada tahun 2014, selama 10 tahun terakhir praktik kecurangan serta tindakan ilegal yang terjadi pada dunia bisnis semakin meningkat. Dimana apabila praktik kecurangan tersebut tetap dibiarkan terjadi dan tidak dicegah, dapat berakibat buruk bagi perusahaan tersebut bahkan dapat menimbulkan terjadinya kebangkrutan. Menurut analisis yang dilakukan oleh organisasi - organisasi internasional dan regulator pemerintah menemukan bahwa penyebab utama praktik kecurangan pada perusahaan adalah karena lemahnya internal control perusahaan (Makhdalena, 2009).

Dalam lingkungan perusahaan, praktik kecurangan yang terjadi seringkali berupa penyalahgunaan aset (asset missappropriation), salah saji pada laporan keuangan (fraudulent statement), dan mengeluarkan biaya perusahaan yang fiktif (frauddulent disbursement) (Tuanakotta, 2010 ; Coram, et al, 2008). Namun tidak menutup kemungkinan bahwa jenis kecurangan yang terjadi akan berbeda pada setiap perusahaan, sebab kecurangan sangat dipengaruhi oleh adanya regulasi dan internal control yang dimiliki oleh setiap perusahaan yang dimiliki oleh setiap perusahaan yang menyebabkan keleluasaan manajemen melakukan kecurangan.

Meningkatnya praktik kecurangan di dalam perusahaan telah meningkatkan kesadaran berbagai negara serta asosiasi usaha untuk melakukan upaya dalam mencegah dan mengurangi adanya praktik kecurangan yang terjadi di perusahaan. Sehingga dibentuklah sebuah kebijakan berupa Good Corporate Governance pada tahun 1990-an untuk diterapkan di perusahaan. Dibentuknya kebijakan tersebut bukan hanya untuk mengurangi dan mencegah praktik kecurangan yang terjadi di perusahaan, melainkan karena adanya regulatory system yang rendah, standar akuntansi dan audit yang tidak konsisten, serta pandangan board of directors yang kurang peduli pada hakhak pemegang saham minoritas (Kharisma, 2014). Penerapan kebijakan Good Corporate Governance merupakan hal penting yang perlu diterapkan di perusahaan, karena dengan penerapa kebijakan tersebut diharapkan dapat menciptakan iklim usaha yang yang baik dan dapat meningkatkan pengendalian internal perusahaan (Wahyudi : 2014).

Pada Praktiknya Good Corporate Governance yang telah digagas sejak tahun 1990-an belum secara maksimal mampu mencegah praktik kecurangan yang terjadi. Hal ini terlihat pada kasus kecurangan yang terjadi pada beberapa perusahaan besar di dunia seperti Enron (2001), Tyco (2002) dan WorldCom (2002) di Amerika, Parmalat (2003) di Italia, HIH Insurance (2001) di Australia, dan PT Kimia Farma (2002) di Indonesia. Skandal kecurangan telah mengakibatkan kerugian yang besar bagi perusahaan, investor, dan stakeholder lainnya. Pada umumnya skandal tersebut terjadi karena lemahnya pengendalian internal perusahaan dan menyebabkan perusahaan tidak dikelola secara efisien, sehingga berpengaruh pada rendahnya kinerja dan pertumbuhan perusahaan. Selain itu, minimnya pengungkapan informasi yang disampaikan kepada publik juga menjadi penyebab tidak berjalannya proses governance (Husaini, 2009).

Skandal - skandal kecurangan yang terjadi, khususnya pada perusahaan - perusahaan di Amerika, memicu kalangan pemerintahan dan legislatif di USA untuk meninjau 
kembali perangkat hukum yang mengatur perusahaan dan praktik akuntan publik. Untuk pengaturan korporat, dikeluarkanlah "SarbanesOxley Act of 2002" pada tahun 2002 (Ludigdo, 2008). Sarbanes-Oxley Act merupakan sebuah undang-undang yang disahkan untuk menghindari penyimpangan keuangan di perusahaan-perusahaan terbuka, termasuk penyalahgunaan laporan keuangan yang dibuat oleh kantor akuntan publik (Semendawai, 2011). Dibawah Sarbanes-Oxley Act, eksekutif perusahaan, direksi, auditor, akuntan, pengacara, dan regulator diadiberikan standar akuntabilitas yang lebih ketat (Jickling, 2008).

Sarbanes-Oxley Act mulai diberlakukan pada akhir Juli 2002, dengan tujuan untuk memperkecil terjadinya kecurangan-kecurangan yang dilakukan oleh perusahaan. Sehingga, diharapkan dapat memperbaiki praktek good corporate governance (Herusetya, 2002). Dalam undang-undang ini, perusahaan diwajibkan untuk membuat kebijakan sistem pelaporan pelanggaran atau whistleblowing system (Olander, 2004). Sistem ini disusun sebagai salah satu upaya untuk mencegah terjadinya kecurangan dan kejahatan di internal perusahaan (Semendawai, 2011). Dengan adanya whistleblowing system perusahaan mendorong dan memberikan perlindungan kepada karyawan untuk melaporkan perbuatan kecurangan yang dilakukan oleh rekanrekan mereka (Dutta : tanpa tahun). Sehingga apabila seorang karyawan melihat adanya kecurangan yang dilakukan oleh rekannya, maka karyawan tersebut dapat melaporkannya kepada pihak yang memiliki kewenangan sehingga upaya pencegahan dan pendeteksian praktik kecurangan dalam perusahaan dapat berjalan optimal (Alam, 2014).
Dalam mempraktekkan kebijakan whistleblowing system, perusahaan diharuskan memiliki komitmen kesediaan pada seluruh karyawan sebagai pihak yang paling berperan dalam melaksanakan sistem tersebut (Semendawai, 2011). Selain itu perusahaan juga harus memiliki pernyataan yang menyatakan bahwa semua laporan atas pelanggaran dan kecurangan harus dijamin kerahasiaannya dan keamanannya oleh perusahaan. Hal ini berguna untuk melindung pelapor (Hazlina, 2009 ; Lee and Fargher, 2012).

Efektivitas

penerapan whistleblowing system dapat dilihat dari banyaknya jumlah kecurangan yang berhasil terdeteksi serta waktu penindakan atas laporan kecurangan lebih singkat. Selain itu, pimpinan perusahaan juga memiliki kesempatan untuk mengatasi permasalahan secara internal terlebih dahulu, sebelum permasalahan tersebut tersebar ke publik dan dapat mempengaruhi reputasi perusahaan (KNKG, 2008).

Di Indonesia, kebijakan sistem pelaporan pelanggaran atau whistleblowing system adalah sebuah sistem pelaporan pelanggaran yang masih baru diterapkan. Whistleblowing system diterbitkan di Indonesia oleh Komite Nasional Kebijakan Governance (KNKG) pada tanggal 10 November 2008 (Kreshastuti dan Prastiwi, 2014). Salah satu faktor yang mendorong untuk penerapan kebijakan tersebut di Indonesia adalah munculnya beberapa kasus kecurangan yang terjadi pada perusahaan besar di negara ini, seperti PT Telkom dan PT Kimia Farma yang terbukti terdapat kecurangan yang dilakukan oleh manajemen perusahaan tersebut (Koroy : 2008). Adanya kebijakan whistleblowing system ini dianggap dapat menjadi alat yang berharga dalam strategi corporate 
governance, sebagai pelaporan insiden pelanggaran yang dapat membantu menjaga keamanan tempat kerja, sekaligus profit dan reputasi perusahaan (Susmanschi, 2012).

Meskipun kebijakan whistleblowing system ini masih baru diterapkan di Indonesia, kesadaran terhadap pentingnya penerapan kebijakan whistleblowing system di perusahaan maupun organisasi pemerintah terus meningkat. Hal ini dengan mulai diterapkannya whsitleblowing system ini oleh perusahaan-perusahaan besarn milik swasta atau BUMN yang telah membentuk dan menerapkan kebijakan whistleblowing system tersebut, seperti Pertamina, United Tractors, Sinar Mas, PT Matahari Departemen Store, Jasamarga dan beberapa perusahaan lainnya. Sehingga berdasarkan latar belakang tersebut penelitian ini ingin mengetahuai faktor-faktor yang mempengaruhi penerapan whistleblowing system di Indonesia.

\section{KAJIAN LITERATUR}

\section{Wishtleblowing system}

Whsitleblowing

system

merupakan bagian dari pengendalian internal perusahaan yang digunakan untuk mengungkapkan pelanggaran yang terjadi dialam perusahaan. Setiap orang yang melaporkan pelanggaran disebut dengan whistleblower. Whistleblower merupakan seorang karyawan atau masyarakat yang melaporkan atas adanya praktik kecurangan yang terjadi di lingkungan perusahaan maupun pemerintahan, dimana laporan tersebut dapat diutarakan langsung oleh pihak internal ataupun pihak eksternal yang mengetahui terjadinya praktik kecurangan. Susmanschi (2012) menambahkan bahwa fenomena whistleblower muncul ketika terdapat laporan dari karyawan yang diduga melakukan kesalahan di tempat kerja yang perlu ditindaklanjuti dengan membuat pengungkapan untuk kepentingan publik.

Seorang whistleblower seringkali dipahami sebagai seorang yang pertama kali mengungkapkan atau melaporkan tindakan yang dianggap ilegal ditempatnya bekerja kepada otoritas internal organisasi atau lembaga pemantau publik. Pengungkapan tersebut tidak selalu didasari dengan itikad baik sang pelapor, tetapi tujuannya untuk mengungkap kejahatan atau penyelewengan yang diketahuinya (Semendawai, 2011).

Menjadi seorang whistleblower bukan hal yang mudah untuk dilakukan, sebelum seorang whistleblower memutuskan untuk mengungkapkan atau melaporkan tindakkan kecurangan yang diketahuinya, ia harus mengetahui terlebih dahulu resiko yang akan terjadi apabila ia melakukan tindakan tersebut. Oleh sebab itu, dibutuhkan cara yang cerdas dan strategis agar keputusan whistleblower untuk mengungkapan adanya kecurangan tidak berdampak buruk pada masa depannya, karirnya serta keluarganya (Davine and Maassarani, 2011).

Terdapat dua kriteria whistleblower. Kriteria pertama, seorang whistleblower menyampaikan atau mengungkapkan laporan kepada otoritas yang berwenang atau media massa. Dengan harapan dugaan atas kejahatan dapat diungkap dan dibongkar. Kriteria kedua, whistleblower merupakan orang dalam, yaitu orang yang mengungkapkan dugaan pelanggaran dan kejahatan yang terjadi di tempatnya bekerja atau ia berada. Sehingga whistleblower benar benar mengetahui dugaan suatu pelanggaran atau kejahatan karena 
berada di dalam tempat ia bekerja (Semendawai, 2011).

Laporan yang diperoleh dari whistleblower perlu mendapatkan perhatian dan tindak lanjut, termasuk juga pengenaan hukuman atau sanksi agar dapat memberikan efek jera bagi pelaku kecurangan dan juga bagi mereka yang terpikir untuk melakukan tindakan tersebut. Tanpa adanya proses penegakan peraturan, semua upaya yang telah dilakukan oleh pelapor akan sia sia (Wijayanto dan Zachrie, 2010).

Dalam tata kelola perusahaan, whistleblower memainkan peran yang sangat penting dalam menyampaikan informasi adanya pelanggaran atau kecurangan yang dapat membantu perusahaan dalam membuat lingkungan kerja lebih aman, selama informasi yang disampaikan memiliki pembenaran (Susmanschi, 2012). Dalam sistem pelaporan pelanggaran (whistleblowing system), seorang whistleblower tidak boleh sembarangan menceritakan kesaksiannya kepada orang lain, institusi lain, atau media massa ketika dia sudah melaporkan adanya dugaan pelanggaran kepada lembaga yang menangani laporan whistleblower. Tujuannya adalah agar lembagalembaga perlindungan saksi atau whistleblower tersebut dapat melindunginya, dan laporan yang diungkapkan dapat diteliti lebih lanjut. Dengan masuknya ke dalam sistem perlindungan saksi, whistleblower memiliki hak-hak yang pantas untuk diterima (Semendawai, 2011).

\section{Pengaruh Total Asset dengan Penerepan Whistleblwoing System}

Sebagai upaya pendeteksian kecurangan yang dilakukan dengan cara whistleblowing, salah satu bentuk kecurangan yang dapat dilaporkan seorang karyawan yang berperan sebagai whistleblower ialah mengenai penyalahgunaan aset milik perusahaan (Coram et al, 2008). Terutama bagi perusahaan yang memiliki total aset besar, cenderung membutuhkan penggunaan whistleblowing system dalam upaya pendeteksian fraud dari pada harus melakukan kontrol secara langsung yang akan menjadi kurang efektif (Caldero'n-Cuadrado et al. (2009) dalam Lee dan Fargher (2012)). Dengan demikian perusahaan yang memiliki total aset yang besar mendorong penggunaan whistleblowing system melalui sebuah saluran pengaduan, seperti hotline. Holder Webb et al. (2008) dalam Lee dan Fargher (2012) secara khusus menemukan bahwa prosedur whistleblowing lebih cenderung diungkapkan oleh perusahaan besar.

$\mathrm{H} 1$ = Terdapat pengaruh signifikan antara total aset perusahaan dengan kecenderungan penerapan whistleblowing system.

\section{Pengaruh Inventory dengan Penerapan Whistleblwoing system}

Salah satu permasalahan yang sering dihadapi oleh perusahaan adalah pengelolaan inventory. Sebab, inventory merupakan aset perusahaan yang cukup besar, sehingga apabila dalam penanganannya tidak dilakukan dengan baik, maka akan menimbulkan kerugian yang cukup besar bagi perusahaan. (Naibaho, 2013). Seperti adanya perangkapan fungsi pencatatan dan penyimpanan pada bagian gudang atau perbedaan jumlah invintory yang signifikan dapat menjadi faktor yang menyebabkan terjadinya kecurangan dalam inventory sehingga dibutuhkan pengendalian internal untuk mencegah terjadinya fraud tersebut (Putra, 2010). Ashbaugh - Skaife et al. (2007) dalam Lee dan Fargher (2012) menyatakan bahwa perusahaan yang memiliki tingkat inventory yang lebih besar 
memungkin lebih meningkatkan kualitas pengendalian internalnya serta menerapkan whistleblowing system yang lebih baik guna meminimalkan resiko penipuan.

$\mathrm{H} 2$ = Terdapat pengaruh signifikan antara inventory perusahaan dengan penerapan whistleblowing system.

\section{Pengaruh Anonymous reporting dengan penerapan Whistleblowing system}

Whistleblowing system merupakan sebuah program yang dapat menerima adanya pengaduan terhadap kecurangan. Dalam menyampaikan pengaduan adanya fraud, sebaiknya dilakukan secara rahasia, hal tersebut bertujuan untuk melindungi pelapor dari adanya ancaman atau dikucilkan oleh rekan kerja pelapor tersebut. Sehingga diterimalah pengungkapan pengaduan dengan cara anonim, dimana pelapor tidak memberikann identitasnya sama sekali (Hazlina, 2009). Sebuah mekanisme umum digunakan untuk memfasilitasi pelapor anonim melalui penggunaan layanan hotline (Worlton, 2005). Dengan demikian, perusahaan yang mengizinkan pelaporan anonim cenderung lebih mendukung whistleblowing system dan diharapkan dapat meningkatkan pengungkapan pelaporan kecurangan lebih besar (Lee dan Fargher : 2012).

H3 = Terdapat hubungan signifikan antara anonymous reporting dengan penerapan whistleblowing system.

\section{Pengaruh External Directors Komite audit dengan penerapan Whistleblowing system}

Menurut Kep-29/PM/2004 dalam (Utami dan Rahmawati, 2008) definisi komite audit adalah komite yang dibentuk oleh dewan komisaris untuk melakukan tugas pengawasan pengelolaan perusahaan. Komite audit merupakan penghubung pihak pemegang saham dan dewan komisaris dan pihak manajemen dalam menangani masalah pengendalian. Fungsi suatu komite audit secara langsung dapat mempengaruhi auditor secara langsung dalam mengkomunikasikan masalah masalah besar yang dijumpai selama pelaksanaan audit (Boynton. Jonson, Kell, 2002). Sehingga dalam mekanisme pengendalian internal dan mendeteksi kecurangan, sebagian besar direksi eksternal pada audit committee dan adanya kepemilikan saham yang terkonsentrasi menekankan untuk menerapkan whistleblowing system dengan tujuan untuk meningkatkan pengawasan (Lee dan Fargher, 2012).

$\mathrm{H} 4$ = Terdapat hubungan signifikan antara external directors komite audit dengan penerapan whistleblowing system.

\section{Pengaruh kepemilikan manajerial dengan penerapan whistleblwoing system}

Salah satu tujuan perusahaan menerapkan kebijakan whistleblowing system adalah untuk mewujudkan good corporate governance, dimana perspektif corporate governance tersebut berawal dari teori agensi. Teori agensi merupakan hubungan antara manajemen dengan pemilik. Manajemen bertindak sebagai agen yang memiliki tanggung jawab untuk mengoptimalkan keuntungan para pemilik (Meilyana, 2012). Menurut Jansen dan Mackling (1976) dalam Zulfikar, Rosiana dan Nariah (2015) kepemilikan manajerial dapat membantu mengurangi masalah agensi, sebab melalui kepemilikan manajerial tindakan oportunis untuk memaksimalkan kepentingan pribadi akan berkurang dan manajer juga akan lebih berhati-hati dalam mengambil keputusan yang sesuai dengan 
kepentingan perusahaan karena terkait dengan kepentingannya sebagai pemilik, sehingga pengungkapan informasi pengendalian internal akan semakin berkualitas. Struktur tata kelola perusahaan dapat menggunakan mekanisme pengendalian internal untuk memastikan kepatuhan, kredibilitas dan pendeteksian kecurangan (Coram et al, 2008). Dalam penelitian yang dilakukan oleh Lee dan Fargher (2012) menyatakan bahwa presentase kepemilkan manajerial memiliki hubungan positif terhadap tata kelola perusahaan dan tata kelola perusahaan yang baik akan meningkatkan pengungkapan yang tersedia dalam kebijakan whistleblowing system.

H5 = Terdapat hubungan signifikan antara kepemilikkan manajerial dengan penerapan whistleblowing system.

\section{METODOLOGI PENELITIAN}

Penelitian ini adalah penelitian deskriptif dengan pendekatan kuantitatif. Cakupan pembahasan meliputi studi empiris pada perusahaan yang terdaftar di Bursa Efek Indonesia yang menerapkan kebijakan whistleblowing system. Penelitian ini bertujuan untuk mengetahui pengaruh penerapan kebijakan whistleblowing system terhadap pencegahan kecurangan dan faktor apa saja yang mempengaruhi implementasinya. Adapun variabel penelitian yang akan dibahas adalah mengenai penerapan whistleblowing system dan pencegahan kecurangan pada perusahaan.

Dalam penelitian ini, jenis data yang digunakan adalah data sekunder dengan jenis waktu pengumpulan data cross section. Pada penelitian ini data diperoleh dari laporan keuangan dan laporan tahunan perusahaan untuk tahun yang berakhir pada 31 Desember 2013 dari perusahaan yang terdaftar di Bursa
Efek Indonesia dari berbagai sektor. Dalam penelitian ini, populasi yang ditetapkan oleh peneliti adalah perusahaan yang terdaftar di Bursa Efek Indonesia. Sample dalam penelitian ini adalah perusahaan yang menerapkan kebijakan whistleblowing system, harapannya perusahaan yang dipilih telah menerapkan kebijakan tersebut dengan efektif.

Dalam penelitian ini, metode analisis data yang digunakan adalah uji asumsi klasik regresi berganda dan uji hipotesis. melakukan uji normalitas, uji multikolinearitas dan uji heterokedasitas. Model penelitian dalam penelitian ini adalah sebagai berikut:

$$
\underset{\mathrm{b}_{3} \mathrm{ANON}_{\mathrm{i}}+\mathrm{b}_{4} \text { AUDC }_{\mathrm{i} .}+\mathrm{b}_{5} \text { PSHM }_{\mathrm{i}}+\mathrm{e}_{\mathrm{i}}}{\text { WBS }_{\mathrm{i}}}+
$$

Keterangan :

$$
\begin{aligned}
& \text { WBS = Penerapan Whistleblowing } \\
& \text { system } \\
& \mathrm{a} \quad=\text { Konstanta } \\
& \mathrm{b}_{1}, \mathrm{~b}_{2}, \mathrm{~b}_{3}, \mathrm{~b}_{4}, \mathrm{~b}_{5}=\text { Konstanta } \\
& \mathrm{TA}=\text { Total Asset } \\
& \text { INV }=\text { Inventory } \\
& \text { ANON }=\text { Anonymous report } \\
& \text { AUDC }=\text { External directors komite } \\
& \text { audit } \\
& \text { PSHM = Proporsi pemegang saham } \\
& \text { e }=\text { error } \\
& \mathrm{i} \quad=\text { Perusahaan } \\
& \text { e } \quad=\text { Error }
\end{aligned}
$$

\section{HASIL DAN PEMBAHASAN}

Dalam penelitian ini objek yang digunakan adalah perusahaanperusahaan yang terdaftar pada Bursa Efek Indonesia pada tahun 2013 yang menerapkan kebijakan whistleblowing system pada setiap sektor, kecuali perusahan pada sektor keuangan dan sektor investasi sebab kedua sektor ini tidak memenuhi syarat dalam penelitian yang dilakukan. Tidak adanya inventory pada sektor keuangan dan sektor 
insvestasi merupakan alasan utama mengapa kedua sektor tersebut tidak dipilih menjadi objek penelitian, karena inventory pada perusahaan merupakan salah satu variabel yang dijadikan pengukuran dalam penelitian untuk mengetahui apakah inventory yang dimiliki oleh perusahaan berpengaruh dalam penerapan kebijakan whistleblowing system. Pada tahun 2013 terdapat 482 peusahaan yang terdaftar pada Bursa Efek Indonesia yang terdiri dari 9 sektor, diantaranya adalah :

Tabel 1. Daftar perusahaan Terdaftar di Bursa efek Indonesia

\begin{tabular}{|c|c|c|c|}
\hline Nomor & Sekto & \multicolumn{2}{|c|}{ Jumlah Perusahaan } \\
\hline 1 & Sektor Per & \multicolumn{2}{|c|}{20} \\
\hline 2 & Sektor Pertar & \multicolumn{2}{|r|}{38} \\
\hline 3 & Sektor Industri Da & \multicolumn{2}{|l|}{ an Kimia } \\
\hline 4 & Sektor Anek: & \multicolumn{2}{|l|}{ Istri } \\
\hline 5 & Sektor Industri Bar & \multicolumn{2}{|l|}{ Konsumsi } \\
\hline 6 & Sektor Properti da & \multicolumn{2}{|l|}{ ll Estate } \\
\hline 7 & Sektor infrastruktur, Utili & \multicolumn{2}{|l|}{ an Transportasi } \\
\hline 8 & Sektor Keu & \multicolumn{2}{|r|}{69} \\
\hline 9 & Sektor Perdagangan, J & \multicolumn{2}{|l|}{ lan Investasi } \\
\hline \multicolumn{4}{|c|}{$\begin{array}{ll} & 480 \\
\text { whistlohlowino } & \text { sustom }\end{array}$} \\
\hline \multicolumn{2}{|c|}{$\begin{array}{l}\text { Dari } 482 \text { jumlah perusahaan } \\
\text { yang terdaftar pada Bursa Efek } \\
\text { Indonesia pada tahun } 2013 \text {, terdapat } 55 \\
\text { perusahaan yang memenuhi syarat } \\
\text { utama untuk dijadikan objek penelitian, } \\
\text { dimana perusahaan - perusahaan } \\
\text { tersebut menerapkan } \quad \text { kebijakan }\end{array}$} & \multicolumn{2}{|c|}{$\begin{array}{l}\text { whistleblowing system (setelah } \\
\text { dikurangi dari perusahaan pada sektor } \\
\text { keuangan dan investasi, serta } \\
\text { perusahaan yang tidak menerapkan } \\
\text { kebijakan whistleblowing system). } \\
\text { Berikut adalah tabel kualifikasi data: }\end{array}$} \\
\hline \multicolumn{4}{|c|}{ Tabel 2. Proses Pengambilan sampel Perusahaan } \\
\hline \multicolumn{4}{|r|}{$\begin{array}{c}\text { Jumlah } \\
\text { Perusahaan }\end{array}$} \\
\hline 1 & \multicolumn{2}{|c|}{ Perusahaan yang terdaftar di Bursa Efek Indonesia tahun 2013} & \\
\hline 2 & \multicolumn{3}{|c|}{ Jumlah Perusahaan di Sektor Keuangan } \\
\hline 3 & \multicolumn{3}{|c|}{ Jumlah Perusahaan pada sektor investasi } \\
\hline \multirow[t]{2}{*}{4} & \multicolumn{2}{|c|}{$\begin{array}{l}\text { Jumlah perusahaan yang tidak melaporakan whsitleblwoing } \\
\text { system dalam laporan tahunan }\end{array}$} & $(343)$ \\
\hline & \multicolumn{3}{|c|}{ Total Sampel } \\
\hline
\end{tabular}




\section{Hubungan Total Aset Dengan Penerapan Whistleblowing System}

H0 : Total aset tidak berpengaruh signifikan dengan penerapan whistleblowing system.

H1 : Total aset berpengaruh signifikan terhadap whistleblowing system.

Dari hasil uji t, variabel total aset memiliki tingkat signifikan sebesar 0,695. Hal ini menunjukkan bahwa $\mathrm{H} 1$ ditolak, dan menerima $\mathrm{H} 0$, sehingga variabel total aset tidak memiliki pengaruh yang signifikan terhadap penerapan whistleblowing system karena tingkat signifikan yang dimiliki variabel total aset lebih besar dari 0,05. Hasil dari penelitian ini tidak sesuai dengan hipotesis yang menyatakan bahwa total aset yang dimiliki oleh perusahaan berpengaruh signifikan terhadap penerapan kebijakan whistleblowing system.

Dari hasil yang didapat, penelitian ini tidak sesuai dengan penelitian yang dilakukan oleh Caldero'n-Cuadrado et al (2009) dalam Lee and Fargher (2012) yang menyatakan bahwa persahaan yang memiliki total aset besar cenderung membutuhkan penggunaan whistleblowing system dalam upaya pendeteksian fraud. Selain itu, Coram et al (2008) juga menyatakan dalam penelitian yang dilakukan bahwa organisasi dengan pengendalian internal yang baik lebih memungkinkan untuk mendeteksi kecurangan dalam bentuk penyalahgunaan aset sebab dengan pengendalian internal yang lebih baik dapat mendorong untuk melakukan tindakan pelaporan diri (whistleblowing) yang dapat membantu mendeteksi dari adanya tindakan kecurangan sehingga kecurangan tersebut dapat dicegah.
Hasil penelitian yang berbeda dengan penelitian sebelumnya disebabkan karena kurangnya variasi pada ukuran perusahaan, sebab perusahaan yang dijadikan sampel dalam penelitian ini adalah perusahaan besar yang sahamnya sudah tercatat di Bursa Efek Indonesia. Sehingga hasilnya tidak sesuai dengan hipotesis penelitian.

Hubungan Inventory Dengan Penerapan Whistleblowing System

HO : Total Inventory perusahaan tidak berpengaruh signifikan terhadap penerapan whistleblowing system.

H1 : Total Inventory perusahaan berpengaruh signifikan terhadap penerapan whistleblowing system.

Dari hasil uji t, variabel inventory memiliki tingkat signifikan sebesar 0,357 lebih besar dari $\alpha=0,05$ maka terima $\mathrm{H} 0$ dan tolak $\mathrm{H} 1$ yang berarti variabel total inventory tidak berpengaruh secara signifikan terhadap penerapan whistleblowing system. Hasil penelitian ini tidak sesuai dengan hipotesis yang menyatakan bahwa total inventory yang dimiliki oleh perusahaan memiliki pengaruh yang signifikan terhadap penerapan whistleblowing system.

Meskipun variabel total inventory tidak berpengaruh secara signifikan terhadap penerapan whistleblowing system, Putra (2010) menyatakan bahwa inventory yang dimiliki oleh perusahaan dapat saja disalahgunakan oleh pihak yang tidak bertanggung jawab, sehingga dibutuhkan pengendalian internal untuk mencegah terjadinya tindakan kecurangan tersebut. Dalam pedoman KNKG (2008) dinyatakan bahwa whistleblowing system merupakan bagian dari sistem pengendalian internal yang dapat dijadikan sumber masukan pada perusahaan untuk melihat lebih jauh 
proses kerja yang memiliki kelemahan pengendalian internal. Naibaho (2013) menyatakan bahwa dengan adanya pengendalian internal yang baik dan teratur dalam mengelola inventory perusahaan akan memudahkan pihak pimpinan perusahaan dalam memperoleh laporan - laporan yang bermanfaat untuk meningkatkan efektifitas dalam menentukan jumlah inventory perusahaan serta mencegah berbagai tindakan kecurangan yang dapat merugikan perusahaan. Dalam penelitian Lee dan Fargher (2012) menyatakan bahwa perusahaan yang memiliki inventory yang besar cebderung untuk meningkatkan kualitas pengendalian internal serta menerapkan whistleblowing system untuk meminimalkan resiko kecurangan.

Sama halnya dengan variabel total aset, hasil yang tidak berpengaruh signifikan pada variabel inventory juga disebabkan karena kurangnya variasi pada ukuran perusahaan, sebab pada penelitian ini sampel yang digunakan adalah perusahaan besar yang sahamnya sudah tercatat pada Bursa Efek Indonesia. Oleh sebab itu, hasilnya tidak sesuai dengan hipotesis penelitian.

\section{Hubungan Anonymous Reporting Dengan Penerapan Whistleblowing System}

H0 : Anonymous reporting tidak berpengaruh signifikan terhadap penerapan whistleblowing system.

H1 : Anonymous reporting berpengaruh signifikan terhadap penerapan whistleblowing

system.

Dari hasil uji $t$, variabel anonymous reporting memiliki tingkat signifikan sebesar 0,000 lebih kecil dari $\alpha=0,05$ maka tolak $\mathrm{H} 0$ dan terima $\mathrm{H} 1$ yang berarti variabel anonymous reporting berpengaruh secara signifikan terhadap penerapan whistleblowing system. Dengan demikian semakin semakin banyak perusahaan yang mengizinkan pelaporan secara anonim cenderung mendukung penerapan whistleblowing system.

Hasil penelitian ini sejalan dengan penelitian yang dilakukan oleh Lee dan Fargher pada tahun 2012 yang menyatakan bahwa beberapa perusahaan besar Australia yang sahamnya cross-listed di Amerika yang mengizinkan pelaporan dalam bentuk anonim cenderung mendukung penerapan whistleblowing system yang diharapkan dapat membantu meningkatkan pengungkapan pelaporan kecurangan yang lebih besar. Dalam penelitian yang dilakukan oleh Putri pada tahun 2012 menyatakan bahwa jalur pelaporan anonymous terbukti lebih efektif dalam mendorong model whistleblowing system, sebab individu lebih memilih untuk menggunakan jalur pelaporan anonymous untuk melaporkan tindakan kecurangan. Selain itu, Hazlina (2009) menyatakan bahwa sebaiknya bentuk laporan pelanggaran secara anonim harus tetap diterima, hal tersebut bertujuan untuk menghargai pihak pelapor yang khawatir akan adanya ancaman yang akan diterima apabila identitasnya diketahui oleh pihak lain.

\section{Hubungan Antara Eksternal Directors Komite Audit Dengan Penerapan Whistleblowing System}

HO : Eksternal directors komite audit tidak berpengaruh signifikan terhadap penerapan whistleblowing system.

H1 : Eksternal directors komite audit berpengaruh signifikan terhadap penerapan whistleblowing system. 
Dari hasil uji t, variabel eksternal directors komite audit memiliki tingkat signifikan sebesar 0,575 lebih besar dari $\alpha=0,05$ maka tolak $\mathrm{H} 1$ dan terima $\mathrm{H} 0$ yang berarti bahwa pada variabel eksternal directors komite audit tidak berpengaruh signifikan terhadap penerapan whistleblowing system. Hasil penelitian ini tidak sesuai dengan hipotesis yang menyatakan bahwa eksternal directors komite audit berpengaruh signifikan terhadap penerapan whistleblowing system.

Hal ini tidak sejalan dengan penelitian yang dilakukan oleh Lee dan Fargher (2012) yang menyatakan bahwa pihak eksternal directors komite audit berkonsentrasi untuk menekankan penerapan whistleblowing system dengan tujuan untuk meningkatkan pengawasan pengendalian internal. Sebab komite audit bertanggung jawab untuk mengawasi laporan keuangan, mengawasi audit eksternal, dan mengamati sistem pengendalian internal perusahaan. Dalam pedoman whistleblowing system yang diterbitkan oleh Komite Nasional Kebijakan Governance pada tahun 2008, peraturan mengenai kebijakan whistleblowing system pada perusahaan yang sahamnya tercatat di bursa berada di bawah tanggung jawab komite audit, sehingga pemantauan dan pelaksanaannya juga diserahkan kepada pihak komite audit. Oleh sebab itu, pihak eksternal directors komite audit juga memiliki peran dalam penerapan kebijakan whistleblowing system pada perusahaan.

\section{Hubungan Antara Kepemilikan Manajerial Dengan Penerapan Whistleblowing System}

HO : Kepemilikan manajerial tidak berpengaruh signifikan terhadap penerapan whistleblowing system.
H1 : Kepemilikkan manajerial berpengaruh signifikan terhadap penerapan whistleblowing system

Dari hasil uji t, variabel kepemilikan manajerial memiliki tingkat signifikan sebesar 0,576 lebih besar dari $\alpha=0,05$ maka tolak H1 dan terima $\mathrm{H} 0$ yang berarti kepemilikan manajerial tidak berpengaruh signifikan terhadap penerapan whistleblowing system. Hasil ini tidak sesuai dengan hipotesis yang menyatakan bahwa kepemilikan manajerial memilili pengaruh signifikan terhadap penerapan whistleblowing system.

Pada umumnya dengan adanya kepemilikan manajerial, manajemen memiliki upaya yang sama dalam memantau pengendalian internal karena adanya adanya keselarasan manajer tujaun manajer dengan tujuan pemegang saham. (Mahariana dan Ramantha, 2014). dimana salah satu upaya untuk memantaunya adalah dengan menerapkan whistleblowing system. Namun dari hasil penelitian yang telah dilakukan, penelitian ini tidak sejalan dengan penelitian yang dilakukan oleh Lee dan Fargher yang menyatakan bahwa dengan adanya kepemilikan manajerial dibutuhkan kebijakan whistleblowing system, yang diiringi dengan adanya fasilitas hotline pada perusahaan untuk memudahkan pelaporan.

Hasil yang tidak sesuai dengan penelitian terdahulu yang telah dilakukan ini disebabkan karena dari 55 sampel perusahaan yang ada, terdapat 40 perusahaan yang tidak memiliki saham yang dimiliki oleh pihak manajemen didalamnya. Oleh sebab itu, hasil yang didapat tidak sesuai dengan hipotesis dan penelitian terdahulu yang telah dilakukan. 


\section{SIMPULAN}

Penelitian ini bertujuan untuk mengetahui pengaruh penerapan whistleblowing system pada perusahaan yang terdaftar di Bursa Efek Indonesia dalam upaya pencegahan kecurangan dan faktor apa saja yang mempengaruhi implementasiaanya. Sampel dalam penelitian ini berjumlah 55 perusahaan yang terdaftar di Bursa Efek Indonesia pada tahun 2013 yang menerapkan kebijakan whistleblowing system. Berdasaekan data yang telah dikumpulkan dan pengujian yang telah dilakukan terhadap permasalahan dengan menggunakan regresi berganda, maka dapat diambil kesimpulan sebagai berikut :

1. Pada variabel total aset dan total inventory tidak berpengaruh signifikan terhadap penerapan kebijakan whistleblowing system,

2. Variabel anonymous reporting berpengaruh signifikan terhadap penerapan whistleblowing system. Pelaporan dalam bentuk anonim cenderug lebih mendorong penerapan kebijakan whistleblowing system, sebab individu akan lebih memilih bentuk pelaporan anonim dalam melaporkan tindakan kecurangan.

3. Variabel eksternal directors komite audit tidak berpengaruh signifikan terhadap penerapan kebijakan whistleblowing system, jumlah eksternal directors komite audit pada perusahaan tidak mendorong untuk meningkatkan kualitas pengendalian internal perusahaan.

4. Variabel kepemilikan saham manajerial tidak berpengaruh signifikan terhadap penerapan kebijakan whistleblowing system, sebab dari data yang diolah terdapat beberapa perusahaan yang tidak memiliki saham manajerial.
Penelitian yang dilakukan ini sangat jauh dari kesempurnaan karena keterbatasan yang dimiliki oleh penulis. Keterbatasan daalam penelitian ini adalah sangat sedikit sampel yang digunakan karena belum banyak perusahaan yang melaporkan jumlah pelanggaran yang terjadi pada perusahaan.

Saran-saran yang diberikan untuk penelitian selanjutnya adalah :

1. Penelitian selanjutnya diharapkan dapat menambah variabel independen lainnya, terutama variabel - variabel yang mempengaruhi penerapan whistleblowing system pada perusahaan. Misalnya variable terkait elemen -elemen good corporate governance

2. Penelitian selanjutnya diharapkan menggunakan level perusahaan yang lebih beragam, agar hasil yang didapat lebih berkualitas dan sesuai dengan yang diharapkan.

\section{DAFTAR PUSTAKA}

Alam, Muhammad Dimar. 2014. Persepsi Aparatur Pemerintah dan Anggota Dewan Perwakilan Rakyat Daerah Kota Malang Terhadap Fraud Dan Peran Whistleblowing Sebagai Upaya Pencegahan Dan Pendeteksian Fraud. jurnal Ilmiah Mahasiswa FEB Vol 2, No 2.

Amrizal, A. 2004. Pencegahan dan Pendeteksian Kecurangan Oleh Internal Auditor. BPKP.

Albrecht, W. Steve. 2009. Fraud Examination, Fourth Edition. Ohio. Cengange Learning.

Boynton, William C., Raymond N. Johnson, Walter G. Kell. 2002. 
Modern Auditing, Edisi Ketujuh, Jilid 1. Erlangga, Jakarta

Coram, P., et al. 2008. Internal Audit, Alternative Internal Audit Structure and The Level of Misappropation of Assets Fraud. Accounting and Finance 48 (543-559).

Devine, Tom and Tarek F. Maassarani. 2011. The Corporate Whistleblower's Survival Guide. California. Berrett Koehler Publishers, Inc.

Dutta, Uttam Kumar. (Tanpa Tahun).Whistle-Blower

Mechanism at Corporate Governance : A Study Based On System. Handbook of Research on Strategic Business Infrastructure Development and Contemporary Issue in Finance.

Hassink, Harold et all. 2007. A Content Analysis of Whistleblowing Policies of Leading European Companies. Journal of Business Ethics $75: 25$ - 44 .

Hazlina binti Shaik Md Noor Alam. 2009. Whistleblowing and Corporate Governance Accidental Allies Or Lifetime Partners. International Conference On Corporate Law (ICCL)

Herusetya, Antonius.2002.Dampak Undang - Undang SarbanesOxley 2000 Terhadap Profesi Akuntan Publik. Jurnal Akuntansi Krida Wacana.
Herjanto, Eddy. 2008. Manajemen Operasi Edisi Ketiga. Jakarta : Grasindo.

Husaini. 2009. Komite Audit \& Audit Internal : Integritas Pengawasan Korporasi. Bandung. Unpad Press.

Jickling, Mark.(Tanpa Tahun). Sarbanes - Oxley and The Competitive Position of U.S. Stock Markets. The Sarbanes Oxley Act Implementation, Significance and Impact.

Juliandi, Azuar, Irfan, dan Saprinal Manurung. 2014. Metodologi Penelitian Bisnis Konsep dan Aplikasi. Medan : UMSU Press.

Karni, Soejono. 2000. Auditing : Audit Khusus dan Audit Forensik Dalam Praktik. Depok. Lembaga Penerbit FE - UI.

Kharisma, Bayu. 2014. Good Governance Sebagai Suatu Konsep dan Mengapa Penting Dalam Sektor Publik dan Swasta : Suatu Pendekatan Ekonomi Kelembagaan. Jurnal Buletin Studi Ekonomi Vol 19, No. 1.

Koroy, Tri Ramaraya. 2008. Pendeteksian Kecurangan (Fraud) Lapora Keuangan Oleh Auditor Eksternal. Jurnal Akuntansi dan Keuangan Vol 10, No.1.

Komite Nasional Kebijakan Governance. 2008. Pedoman Sistem Pelaporan Pelanggaran - SPP (Whistleblowing System $-W B S)$. 
Krehastuti, Destriana Kurnia dan Andri Prastiwi. 2014. Analisis Faktor - Faktor yang Mempengaruhi Intensi Auditor Untuk Melakukan Tindakan Whistleblowing (Studi Empiris Pada Kantor Akuntan Publik di Semarang. Diponogoro Journal Of Accounting Vol 3, No 2.

Lee, Gladys and Neil Fargher. 2013. Companies' Use Whistleblowing to Detect Fraud : An Examination of Corporate Whistle-Blowing Policies. Journal Business Ethics 114 : 283 - 295.

Lind, Douglas A., Marchal, William G., dan Wathen, Samuel A.. 2008. Teknik - Teknik Statistik Dalam Bisnis dan Ekonomi Menggunakan Kelompok Data Global 2 Edisi 13. Jakarta : Salemba Teknik.

Lipman, Frederick D.. 2012. Whistleblowers Incentives, Disinvectives, and Protection Strategies. New Jersey. John Wiley \& Sons.

Ludigdo, Unti. 2008. Makna Uang Dalam Konstruksi Kesadaran Etis Akuntan. Jurnal Tema Vol 9, No. 1

Mahariana, I Dewa Gede Pingga dan I Wayan Ramantah. 2014. Pengaruh Kepemilikkan Manajerial Dan Kepemilikkan Institusional Pada Manajemen Laba Perusahaan Manufaktur Di Bursa Efek Indonesia. EJurnal Akuntansi Universitas Udayana, Vol 7, No. 2.
Makhdalena. 2009. Internal Control : Meningkatkan Pengawasan dan Pengendalian. Jurnal Pendidikan Ekonomi dan Bisnis, Vol 1, No. 3.

Meilyana, Elizabeth. 2012. Analisis Pengaruh Mekanisme Corporate Governance Terhadap Manajemen Laba Dan Nilai Perusahaan Pada Perusahaan Manufaktur Di BEI. Berkala Ilmiah Mahasiswa Akuntansi, Vol 1,No.3.

Nachrowi, Djalal Nachrowi dan Herdius Usman. 2006. Pendekatan Populer dan Praktis Ekonometrika Untuk Analisis Ekonomi dan Keuangan. Depok : LP - FEUI.

Naibaho, Alex Tarukdatu. 2014. Analisis Pengendalian Internal Persediaan Bahan Baku Terhadap Efektifitas Pengelolaan Persediaan Bahan Baku.Jurnal Riset Ekonomi, Manajemen, Bisnis Dan Akuntansi, Vol 1. No. 3.

Nixson, Syarifuddin Kalo, dkk. 2013. Perlindungan Hukum Terhadap Whistleblower dan Justice Collabolator Dalam Upaya Pemberantasan Tindak Pidana Korupsi. USU Law Journal, Vol 2, No.2.

Olander, Susan. 2004. Whistleblowing Policy : An Element of Corporate Governance. Academic Journal Article. Management Quarterly, Vol 45, No. 4 
Putra, Yuniarti Hidayah Suyoso. 2010. Praktik Kecurangan Akuntansi Dalam Perusahaan. El Muhasaba, Vol 1, No. 1.

Putri, Caesar Marga. 2012. Pengujian Keefektifan Jalur Pelaporan Pada Structural Model Dan Reward Model Dalam Mendorong Whistleblowing : Pendekatan Eksperimen. SNA 15 Banjarmasin, No. 097. Universitas Lambung Mangkurat.

Rasyad, Rasdihan. 2003. Metode Statistik Deskriptif Untuk Umum. Jakarta : Grasindo.

Santoso, Singgih. 2010. Statistik Multivariat. Jakarta : Elex Media Komputindo.

Semendawai, dkk. 2011. Memahami Whistleblower. Jakarta. Lembaga Perlindungan Saksi dan Korban.

Soegoto, Eddy Soeryanto. 2008. Marketing Research The Smart Way To Solve A Problem. Jakarta : Elexmedia Komputindo.

Sugiyono. 2012. Metode Penelitian Kualitatif Kuantitatif dan $R \& D$. Jakarta : Alfabeta.

Suharyadi dan Purwanto S.K.. 2009. Statistika : Untuk Ekonomi dan Keuangan Modern, Edisi 2 Buku 2. Jakarta : Salemba Empat.

Susmanchi, Georgiana. 2012. Internal Audit and Whistle-Blowing. Economics, Management, and Financial Markets, Vol 7 (4), 415-421.
Tuanakotta, Thodorus M.. 2010. Akuntansi Forensik dan Audit Investigatif, Edisi 2. Jakarta : Salemba Empat.

Utami, Rini Budi dan Rahmawati. 2008. Pengaruh Komposisi Dewan Komisaris Dan Keberadaan Komite Audit Terhadap Aktivitas Manajemen Laba Pada Perusahaan Manufaktur Yang Terdaftar Di Bursa Efek Jakarta. Prosiding Seminar Ketahanan Ekonomi Nasional (SKEN) UPN "Veteran" Yogyakarta.

Wahyudi, Dudi. 2014. Dampak Penerapan Good Corporate Governance Terhadap Kepatuhan Pajak Perusahaan. Diakses dari www.bppk.depkeu.go.id pada tanggal 14 Maret 2015, <http://www.bppk.depkeu.go.i d/publikasi/artikel/167-artikelpajak/19453-dampakpenerapan-good-corporategovernance-terhadapkepatuhan-pajak-perusahaan>

Worlton, Amy E.. 2005. EU Widens Security ofSOX Whistleblower Hotline. Diakses dari www.wileyrein.com pada tanggal 11 Maret 2014, <http://www.wileyrein.com/pu blications.cfm? $\mathrm{sp}=$ articles\&ne wsletter $=4 \& i d=220>$.

Zulfikar, Rudi, Rita Rosiana dan Ratu Ayu Fanisa Nariah. 2015. Corporate Governance dan Pengungkapan Pengendalian Internal. Jurnal Akuntansi Kajian Ilmiah Akuntansi, Vol 
CYNTIA AYU WARDANI, SULHANI/ Analisis Faktor-Faktor Yang Mempengaruhi Penerapan Whistleblowing System Di Indonesia

1, No 2, Januari 2015. ISSN : 2339 - 2436. 